UNIVERSITY

of DEBRECEN

FACULTY OF

HeALTH

NYÍREGYHÁZA

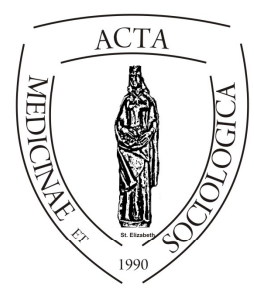

ACTA

MedSoc

Volume 8.

2017

\title{
Életminőség, betegségteher és hozzátartozó terhe a neuropszichiátriai tünetek tükrében neurokognitív zavarokban
}

\author{
Majer Réka ${ }^{1}$, Csiba László ${ }^{2}$, Kardos László $^{3}$, Frecska Ede ${ }^{1}$, \\ Hortobágyi Tibor $^{4}$ \\ ${ }^{1}$ Debreceni Egyetem, Egészségügyi Kar, Pszichológia Tanszék, Nyíregyháza \\ ${ }^{2}$ Debreceni Egyetem Klinikák Központ, Neurológiai Klinika, Debrecen \\ ${ }^{3}$ Kenézy Gyula Kórház és Rendelöintézet, Klinikai Farmakológiai, \\ Infektológiai és Allergológiai Intézet, Debrecen \\ ${ }^{4}$ Debreceni Egyetem, Általános Orvosi Kar, Patológiai Intézet, \\ Neuropatológiai Tanszék; Debrecen
}

\begin{abstract}
Absztrakt.
Háttér és cél. Kutatásunk tárgya annak vizsgálata volt, hogy a neurokognitív zavarokban szenvedő betegek neuropszichiátriai tünetei milyen kapcsolatban vannak a betegek életminőségével, a betegség terhével, a napi aktivitás károsodásával, és a hozzátartozó terhével.

Módszer. Kutatásunkban a Debreceni Egyetem Klinikai Központ Neurológiai Klinikáján és Pszichiátriai Klinikáján gondozott demens betegek neuropszichológiai vizsgálatát végeztük el $(\mathrm{n}=131)$. A neuropszichológiai vizsgálat a következő módszerekből áll: MMSE, ADAS-Cog, NPI, WBI-5, IIRS, ADL I-II. Az eredmények elemzése standard statisztikai vizsgálatokkal történt.
\end{abstract}


Eredmények. Kimutattuk, hogy a neurokognitív zavarban szenvedő betegek körében nagyon magas az NPS tünetek elörefordulási gyakorisága és súlyossága, és erős szignifikáns kapcsolatot találtunk ezek és az életminőség, betegségteher közt. Emellett szignifikáns összefüggést találtunk számos tünet és a hozzátartozó terhe közt.

Következtetések. A magatartási és pszichés tünetek jelentős részei a demens betegek tüneti képének, meghatározzák a betegek életminőségét, és hozzájárulnak a hozzátartozó terhének alakulásához, ezért szükséges ebben az irányban további vizsgálatokat végezni a jobb edukálás érdekében, melynek végső célja, hogy a beteget hosszabb ideig saját otthonában, családja körében lehessen tartani.

\section{Rövidítések}

- $\quad$ NPS=neuropszichiátriai tünetek

- WHO Jól-lét Index rövidített változata=WBI-5

- Betegségteher Index=IIRS

- $\quad$ Mini Mentál teszt=MMSE

- Alzheimer Értékelős Skála-kognitív skála= ADAS-Cog

- Neuropszichiátriai mérőskála=NPI

Kulcsszavak: demencia, Alzheimer-kór, vaszkuláris demencia, magatartási és pszichés tünetek, neuropszichiátriai tünetek, neurokognitív zavarok

Abstract. Quality of life, illness intrusiveness and burden of relatives regarding to
neuropsychiatric symptoms and neurocognitive disorders.
Background and objectives. The subject of our research was to discover the correlation of neuropsychiatric symptoms of neurocognitive disorder patients to quality of life, illness intrusiveness, and deterioration of everyday activity and burden of relatives of patients.

Method. In our research we carried out neuropsychological examinations on dementia patients nursed in Neurology and Psychiatry of Medical Centre of University of Debrecen $(n=131)$. Neuropsychological examination consists of the following methods: MMSE, ADAS-Cog, NPI, WBI-5, IIRS. Analysis of results was made by statistical observations.

Results. We discovered high frequency and seriousness appearance of NPS symptoms in neurocognitive disorder patients, and we found strong significant correlation of them and among quality of life, illness intrusiveness and deterioration of everyday activity. Moreover we discovered significant connection between burden of relatives and number of symptoms.

Conclusions. Behaviour and psychic symptoms are significant parts of symptomatic image of dementia patients, they determine the patients' quality of life, and contribute to the burden of relatives; therefore further examinations should be measured for better education, because the ultimate objective of this is to stay patients in their own flat in the midst of their family.

Keywords: Dementia, Alzheimer's disease, vascular dementia, behaviour and psychic symptoms, neuropsychiatric symptoms, neurocognitive disorders

DOI: $10.19055 / \mathrm{ams} .2017 .8 / 24 / 3$ 
A demencia a 21. század legkritikusabb demográfiai kihívása, mivel a magas életkor a demencia legfóbb rizikófaktora. (WHO Alzheimer's Association, 2010). A WHO elörejelzése szerint 2050-re a világ népességéből 2 milliárd ember lesz 60 év feletti. Világszerte évi 8 millió új demens esetet diagnosztizálnak, ami 4 másodpercenként jelent egy új demens beteget. 2050-re már évi 25 millió új demens beteget jósolnak. Az esetszámok gyors növekedése azonnali cselekvést tesz szükségessé, föleg az alacsony és közepes jövedelmü országok esetében. 2013-ban több mint 15 millió családtag és gondozó közel 17,7 milliárd órányi ellátást nyújtott demens betegnek, melynek kifizetett értéke több mint 220 milliárd dollár. A betegséggel járó költségeket évi 604 millió dollárra becsülik, ami a meghaladja a globális GDP 1\%-t. Ezért a demencia nem csak a beteg, a családja, és szükebb környezetének problémája, hanem össztársadalmi probléma, gazdaságilag és szociálisan egyaránt. (Alzheimer's Association, 2014)

A költségek szempontjából a legnagyobb problémát a neurokognitív zavarokban a neuropszichiátriai tünetek (továbbiakban NPS) jelentik (Lyketsos, Carrillo és munkatársai, 2011). Ide tartozik az agitáció, agresszió, irritabilitás, aktivitászavarok, gátlástalan viselkedés, hangulatzavarok, szorongásos-zavarok, hallucinációk, téveszmék, alvászavarok, étvágyzavarok. Az NPS tünetek a betegség bármely szakaszában előfordulhatnak változó gyakorisággal és súlyossággal. AZ NPS tünetek fontosságát az adja, hogy nem megfelelő kezelés esetén siettetik a betegség progresszióját, rontják a napi aktivitást, csökkentik az életminőséget, növelik az egészségügyi ellátás igénybevételét, ezáltal növelik a költségeket és felgyorsítják az idősek otthonába kerülést (Cooper, Sommerlad, és munkatársai, 2015).

A nemzetközi Alzheimer Szövetség, 2010-ben kerekasztalt hívott össze, melynek célja és témája a neuropszichiátriai tünetek voltak, és előrevetítették a kutatások irányvonalát, mind a gyógyszerfejlesztések, mind az egyéb tudományterületek tekintetében (Lyketsos, Carrillo, és munkatársai, 2011). Az irodalmi adatok szerint a korábban másodlagosnak tartott tünetcsoport sokkal nagyobb hangsúlyt kap a beteg életminősége szempontjából, és fontos meghatározója a beteg distresszének, a gondozó terhének és a betegség kimenetének. (McKeith, Cummings, 2005)

Egy 2016-ban megjelent áttekintő tanulmány (Feast, Orrell, és munkatársai, 2016) rávilágított arra, hogy a demenciához társuló NPS tünetek milyen nagy hangsúlyt kapnak a mindennapi életvitel során. Mind a beteg mind a hozzátartozó pszichés jól-létét és életminőségét nagyban meghatározza. A tanulmány azt hangsúlyozta, hogy a hozzátartozó számára a beteg már évekkel a fizikai halála előtt személyiségében meghal, elkerülhetetlenül elveszíti identitását, gyerek szerepbe esik vissza. A beteg passzív, érdektelen, motiválatlan. Az ezekből adódó szituációs problémák sokszor növelik az agressziót. Emellett megjelenik a 
nemi és szociokulturális normáknak az áthágása, ami miatt nő a kirekesztettség, elszigetelődés.

A demenciákhoz tartozó kognitív tünetek megkülönböztetése, felismerése és a súlyosság detektálása a klinikus számára egyszerúbb feladat, mint az egyéb tünetek felismerése és kezelése. Részben ezért is ezek nagyobb figyelmet kaptak mind a klinikusok mind a kutatók részéről. Az NPS tünetek sokáig a gerontopszichiátria elhanyagolt területének számítottak. Holott egy tesztelési és gondozási stratégia kidolgozása nagyon sürgős és hasznos lenne az NPS tünetek megelözésében és kezelésében. Szükségessé vált egy olyan nem gyógyszeres megközelítés kidolgozása és alkalmazása, mely megkönnyíteni a demens betegek gondozását a mindennapokban, a beteg és a hozzátartozó számára egyaránt. (Gitlin, Piersol és munkatársai, 2016)

Az NPS tünetek jelentőségét az adja, hogy nagyban megnöveli a morbiditást és a mortalitást. Az egyensúlyzavar, elesések, inkontinencia, táplálkozási és alvászavarok mind okai, mind következményei lehetnek a NPS tüneteknek. Egyensúlyzavarok, elesések az agitált magatartás részeként fordulnak elö, akár 35-40\%-os gyakorisággal. Vazoregulációs és vegetatív zavarokra vezethetők vissza. Az inkontinencia igen gyakori. A szfinkter kontroll centrális zavarát a cinguláris és a prefrontális kortex diszkonnekciója okozhatja és szinte minden demenciaformában gyakori. Az inkontinenciaproblémák másodlagos elesésekhez vezethetnek, fürdőszobába sietés stb. Társuló szövődmény az infekciók, fájdalom. A demens betegek 12-50\%-a táplálkozási nehézségekkel küszködik. Évente 4\%-os súlyvesztés jósolható meg. Ez igen fontos mortalitási prediktor. Az alvászavarok gyakorisága a demencia súlyosbodásával nő (13-40\%). A legsúlyosabb esetekben a napi cirkadián ritmus teljes felborulás következik be (Kálmán, Kálmán, Pákáski, 2008).

Azok a személyek, akik NPS tünetekkel élnek izolációt, félelmet, csökkent életminőséget, megnövekedett morbiditást és mortalitás tapasztalnak és megnövekednek az egészségügyi költségeik (Clare, Rowlands és munkatársaik, 2008).

Kutatásunk hosszú távú célja egy olyan stratégia kidolgozása, mely hosszú távon segítséget és támogatást nyújthat a neurokognitív zavarban szenvedő betegeknek és hozzátartozóiknak. Ennek a kidolgozásának az első lépése egy keresztmetszeti vizsgálat hazai mintán a neuropszichiátriai tünetek felmérésére és az ehhez kapcsolódó életminőség, betegségteher és hozzátartozói teher felmérésére. 


\section{Minta és módszerek}

A vizsgálatba a Debreceni Egyetem Klinikák Központ Pszichiátriai Klinika Gerontopszichiátriai és a Neurológiai Klinika Demencia szakrendelésén 2013 február és 2015 április közt első alkalommal megjelent demens betegekből válogattunk be. A vizsgálatba azok a betegek kerülhettek be, akik a háziorvosuk beutalása által első alkalommal jelentek meg a szakrendelésen, saját otthonukban éltek, nem intézetben, és a megjelenés alkalmával velük volt egy hozzátartozó is. Kizárási kritérium volt a krónikus depresszió, látás és/vagy hallászavar, egyéb pszichiátriai betegség. A vizsgálatokat a beteggel és a hozzátartozóval közösen végeztük el. A betegek és a hozzátartozók a vizsgálat megkezdése elött szóbeli tájékoztatásban részesültek, és beleegyező nyilatkozatot írtak alá. A vizsgálatba összesen 131 beteg került be, átlagéletkor 77 év, SD=8,3. Ebböl 48 férfi, átlagéletkor: 74 év $\mathrm{SD}=9,12$, és 83 nő, átlagéletkor: 78,77, $\mathrm{SD}=7,31$. A nemek és az életkorok tekintetében nincs szignifikáns különbség, $\mathrm{p}>0,05$.

A betegek vizsgálata a hozzátartozóval együtt történt. A vizsgálat elején átbeszéltük az anamnézist a hozzátartozóval, majd a NPS tünetek, az életminőség, a betegségteher felmérése a hozzátartozóval együttmüködve történt. Ezután a beválasztott betegekkel egy részletes neuropszichológiai vizsgálatot végeztünk. A vizsgálat időtartama megközelítőleg 45-50 percet vett igénybe.

A betegeket az anamnézis, a vizsgálati eredmények, a képalkotó vizsgálatok eredményei és a szakorvos javaslata alapján 3 csoportba soroltuk, aszerint, hogy milyen típusú demenicáról beszélhetünk. A három csoport az Alzheimer csoport, a vaszkuláris csoport és a kevert csoport.

A vizsgálatban a következő módszereket használtuk. A demográfiai adatok (születési idő, családi állapot, gyerekek száma, iskolai végzettség, foglalkozás), és a részletes anamnézis felvételét követően a következő teszteket használtuk:

- WHO Jól-lét Index rövidített változata (Well-Being Index, továbbiakban WBI-5): A Jól-lét Skála az egyik leggyakrabban használt mérőeszköz, amelyet a pszichológiai jól-lét önértékelésen alapuló mérésére használnak a klinikai vagy a követéses vizsgálatokban. WHO Általános Jól-lét Skálájának 5 tételes változata a személyek általános közérzetéről kíván információt nyújtani az elmúlt kéthetes időszak alapján. ( Susánszky, Konkoly és munkatársai, 2006)

- Betegségteher Index (Illnes Intrusiveness Rating Scale, továbbiakban IIRS): Devins és munkatársai által kifejlesztett rövid kérdőív a betegségteher mérésére szolgál. 13 itemet tartalmaz, 1-7 között terjed az itemek pontozása. A magasabb pontszám nagyobb betegségterhet jelent. A koncepció értelmében a betegség a beteg egyén számára fontos tevé- 
kenységek korlátozása révén hat az életvitelére és az életminőségre, ezt nevezzük betegségtehernek. (Novak, Mah és munkatársai, 2005)

- Mini Mentál teszt (Mini Mental Scate Examination, továbbiakban MMSE) Mini Mental State a nemzetközi gyakorlatban legelterjedtebb gyors kognitív szürővizsgálat. (Folstein, Folstein, McHugh, 2002)

- Alzheimer Értékelős Skála-kognitív skála (Alzheimer Disease Assessment Scale-Cognitive Test, továbbiakban ADAS-Cog): Az egyik leggyakrabban használt kognitív méröskála az Alzheimerrel-kapcsolatos klinikai diagnosztikus munka és kutatás során. 12 altesztből épül fel, melyek alapján megbízhatóan alkalmazható a betegek diagnosztikája, állapot-meghatározása és nyomon követése során. Bár a tesztet elsősorban az Alzheimerben használják, a próbák általánosíthatósága miatt széles körben elterjedt más oki hátterü demenciákban is. (Rosen, Mohs és Davis, 1984, és Pákáski, Drótos és munkatársai, 2012)

- Neuropszichiátriai mérőskála (Neuropsychiatric Inventory, továbbiakban NPI): Cummings, Mega és munkaársai, 1994). Az NPI tizenkét kérdéscsoportból áll, melyet a gondozóval történő interjú alapján tölt ki a kezelőorvos. Klinikai farmakológiai vizsgálatokban gyakran használják a farmakoterápia hatékonyságának megítélése céljából. Három dimenzióban vizsgál 12 tünetet, a tünet gyakorisága, a tünet súlyossága és a hozzátartozó terhe szempontjából. A felvétele kb. 10-15 percet vesz igénybe.

Az adatok kezeléséhez és elemzéséhez a Stata (StataCorp. 2009. Stata Statistical Software: Release 11. College Station, TX StataC) statisztikai programot használtuk. A változók elemzése anonimizált formában, kódok segítségével történt. $\mathrm{Az}$ adatok elemzése során $\mathrm{p}<0,05$ tekintettük szignifikáns különbségnek. Az adatok elemzéséhez a következő módszereket használtuk: ANOVA, KruskalWallis próba, Fisher egzakt teszt, Pearson-féle khi négyzet próba.

\section{Eredmények}

A kognitív funkciók mérésére használtuk a MMSE tesztet és az Adas-Cog-ot. A MMSE átlagpontszám 17,3 +/- 5,69. Az Adas-Cog átlagpontszáma 39,64+/14,15 .

Az NPS tünetek vizsgálatára az NPI skálát használtuk. A kérdőív esetében vizsgáltuk az összpontszámokat és az egyes tüneteket is. Az NPI átlaga 44,09 +/22,73. NPI gyakoriság átlaga $14.58+/-7.55$. NPI súlyosság átlaga $12.87+/-6.42$. 

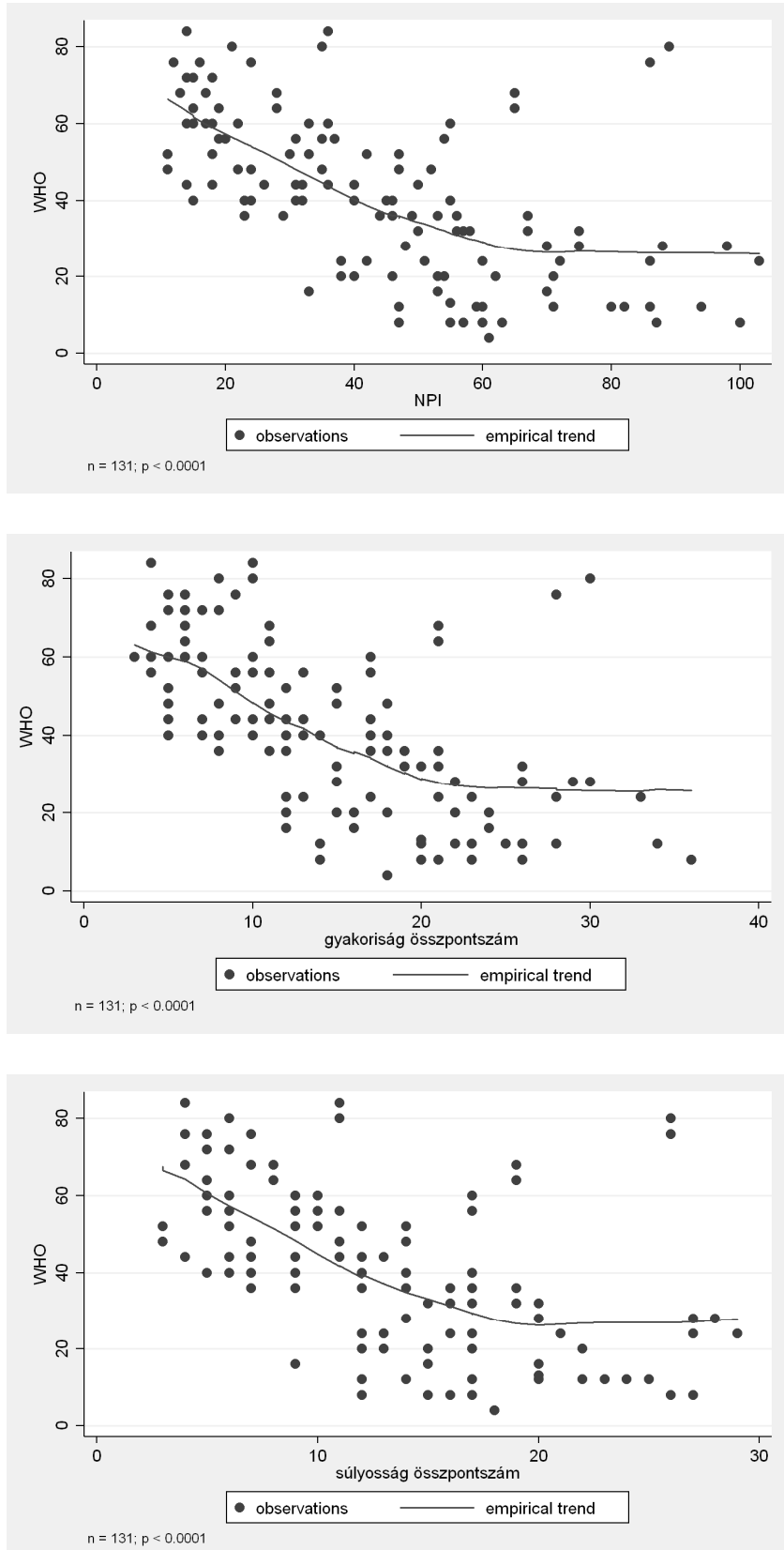

1. ábra. Az életminőség és a neuropszichiátriai tünetek. 


\section{Életminőség és a neuropszichiátriai tünetek}

A WBI-5 átlaga 40, 55 +-21,1. Az életminőség az NPI összpontszámmal, a súlyossággal és a gyakorisággal erős szignifikáns összefüggést mutat (1. számú ábra) Minden esetben a p $<0,001$, mely alapján az NPS tünetek romlásával csökken a beteg életminősége.

\section{Betegségteher és a neuropszichiátriai tünetek}

A IIRS átlaga 45,49 +-11,96. A három csoport közt nincs szignifikáns különbség, $\mathrm{p}>0,05$. A betegségteher mind az NPI összpontszámmal, mind a súlyosság és gyakoriság mutatóval erős szignifikáns kapcsolatot mutat, $\mathrm{p}<0,001$ (2. ábra), mely alapján az NPS tünetek változásával nő a betegség pszichés terhe.
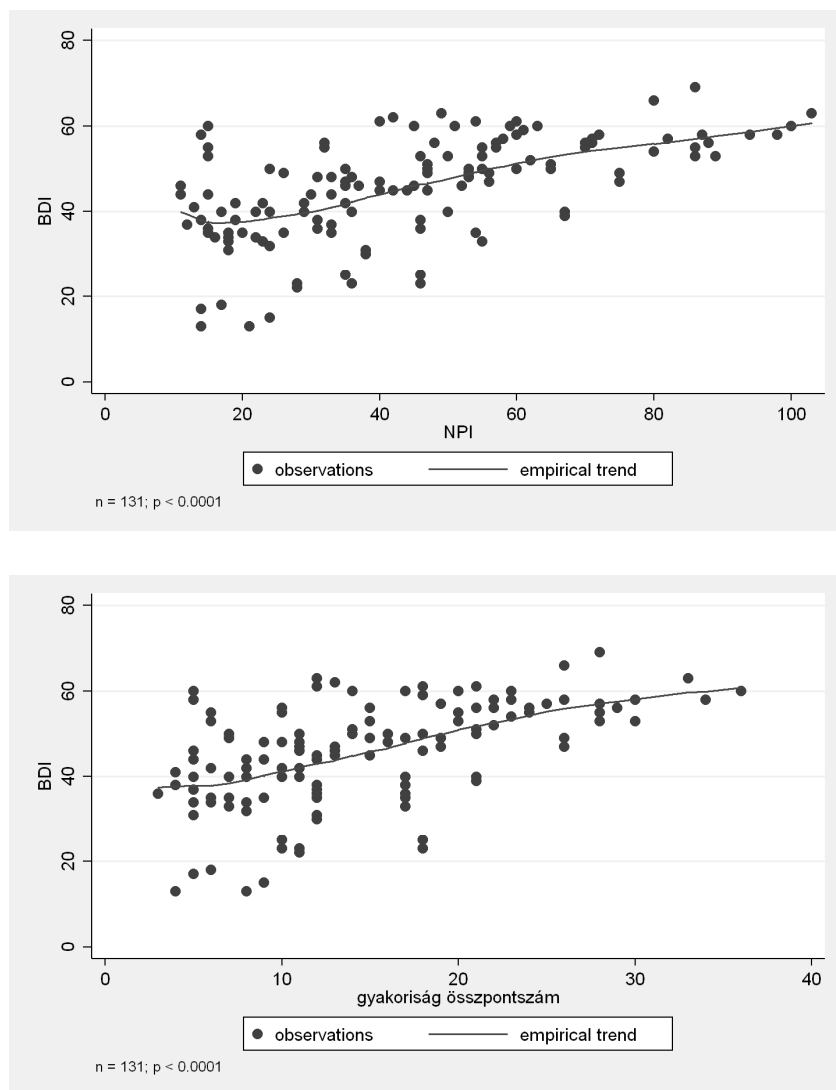


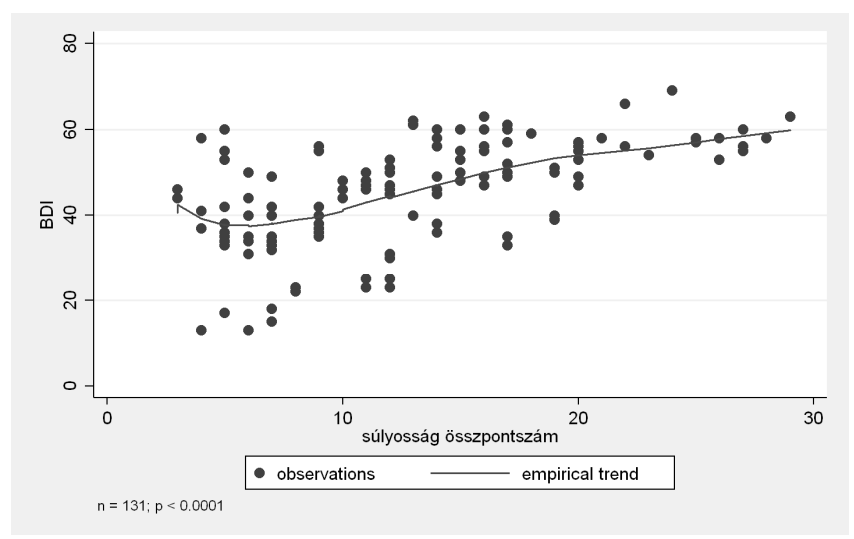

2. ábra. A betegségteher és a neuropszichiátriai tünetek.

\section{A hozzátartozó terhe és a neuropszichiátriai tünetek}

A hozzátartozó terhének mértékét az NPI teszt hozzátartozó terhének mutatója alapján mértük, ezt a továbbiakban zavaró faktornak nevezzük. Az adatok alapján a legmagasabb pontszámot a kóros motoros magatartás, depresszió, agitáció, evés-étvágy változás, téveszme, éjszakai kórtünetek érték el (3. ábra).

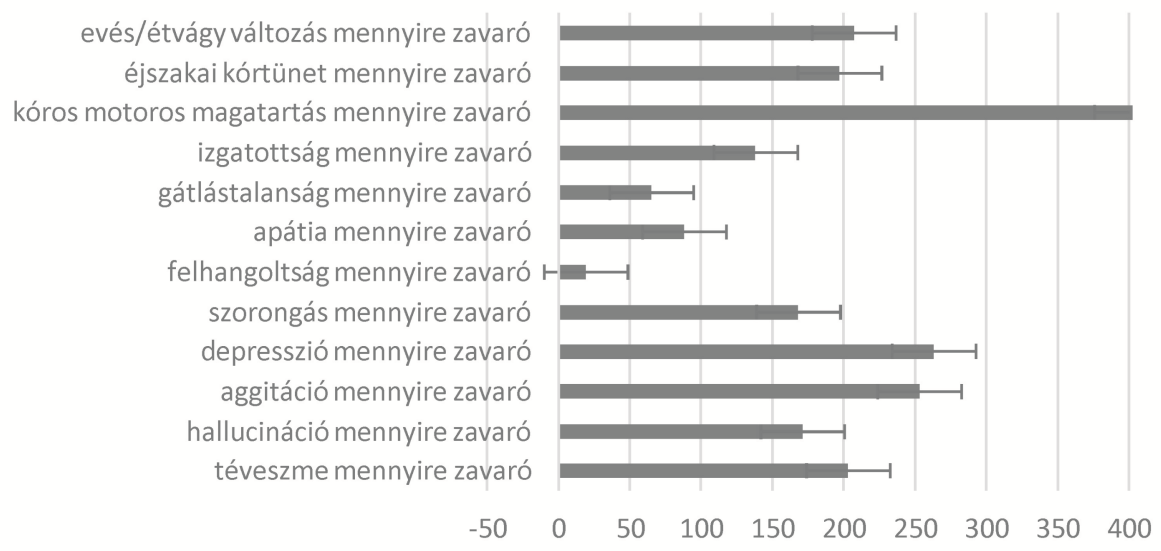

3. ábra. NPI teszt hozzátartozó terhének mutatója.

Mivel az összpontszámok tekintetében nem találtunk szignifikáns eltérést, megvizsgáltuk, hogy a tüneteket egyesével nézve van-e csoportok közti különbség. Azoknál a tünetek esetében, ahol az előfordulási gyakoriság és/vagy súlyosság 
szignifikáns eltérést mutatott a három csoport közt, szignifikáns eltérést tapasztaltunk a zavaró faktor esetében is (4. számú ábra). Hallucináció zavaró faktor, $\mathrm{p}=0,0013$. Kóros motoros magatartás zavaró faktor, $\mathrm{p}=0,0258$. Téveszme zavaró faktor, $\mathrm{p}=0,023$. Felhangoltság zavaró faktor, $\mathrm{p}=0,021$. Depresszió zavaró faktor, $\mathrm{p}=0,0106$.

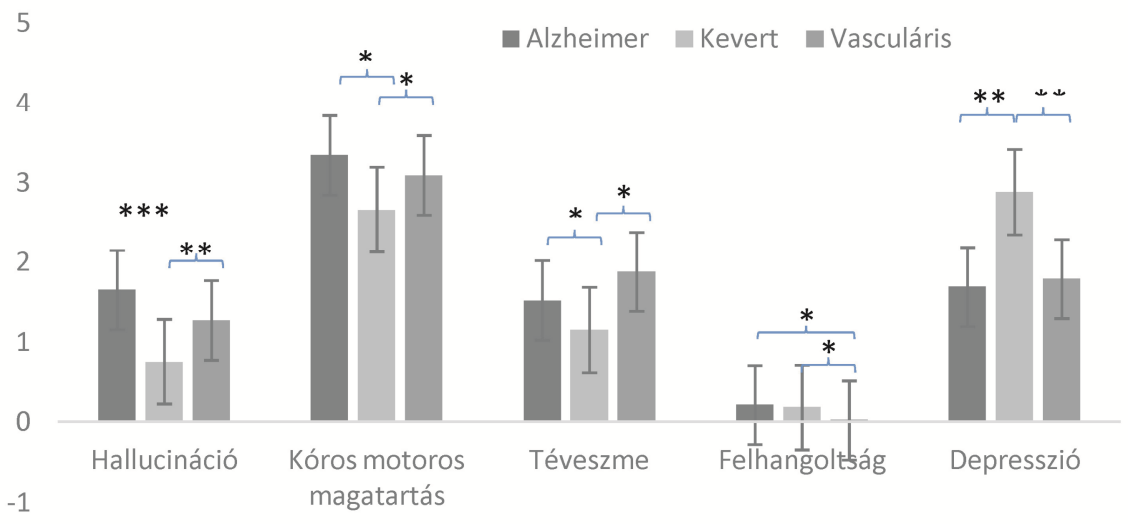

4. ábra. A hozzátartozó terhének szignifikáns eltérései.

Megvizsgáltuk azt is, hogy a hozzátartozó terhének mutatója milyen kapcsolatban van az NPS tünetek összpontszámával, a súlyossággal és a gyakorisággal. Mindhárom esetben erős szignifikáns összefüggést láttunk $p<0,001$, mely alapján az NPS tünetek gyakoribbá válásával és súlyosbodásával nő a hozzátartozó terhe (5. ábra).

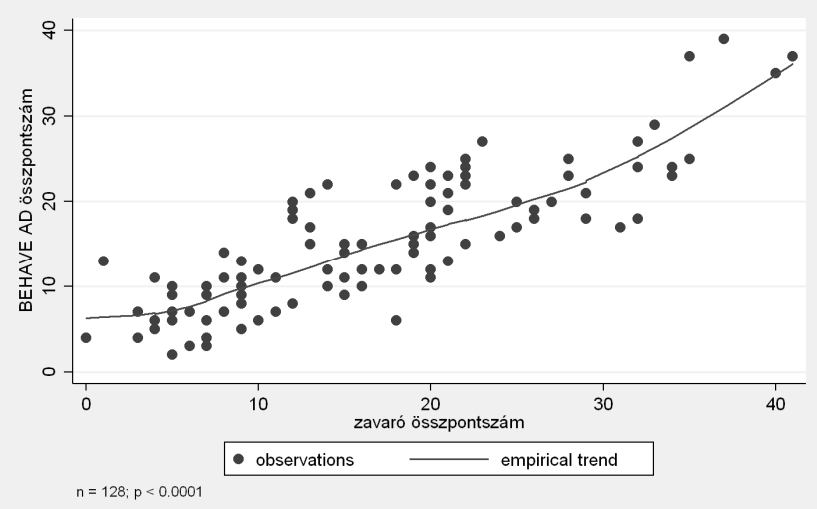



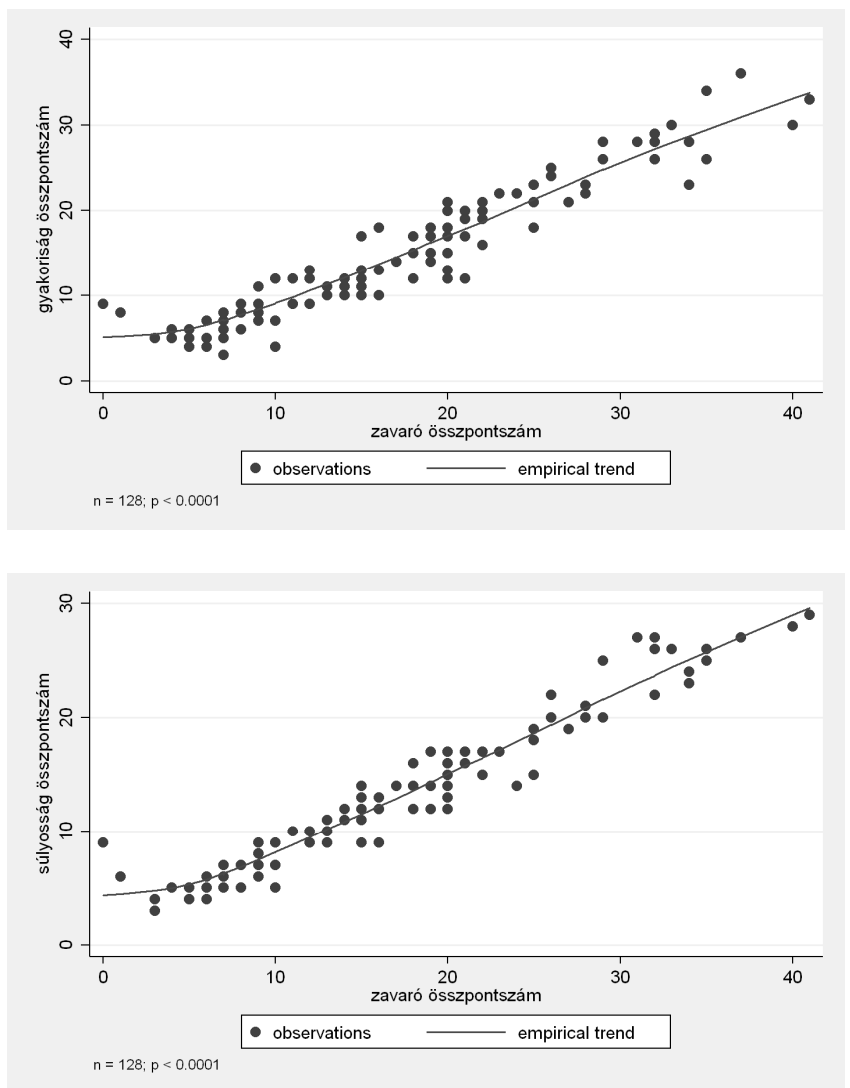

5. ábra. Neuropszichiátriai tünetek és a hozzátartozó terhe.

Hozzátartozó terhe és a kognitív funkciók kapcsolata

Megvizsgáltuk azt is, hogy a kognitív funkciók és az NPS tünetek közt milyen összefüggések vannak. A kognitív funkciót mérő eljárás és a zavaró mutató összpontszáma közt erős szignifikáns kapcsolat van, p<0,001, mely alapján a kognitív funkciók rosszabbodásával nő a hozzátartozó terhének mértéke (6. ábra).

\section{Megbeszélés}

Az NPS tünetek jelentős szenvedést és rossz életminőséget okoznak, mind a betegeknek mind a hozzátartozóknak (Ryu, Ha és munkatársai, 2011). Általános 
egyetértés van abban a tekintetben, hogy minden betegnél megjelennek az NPS tünetek. Már a kognitív tünetek korai szakaszában is $35-85 \%$ a tünetek becsült megjelenési átlaga (Monastero, Mangialasche és munkatrsai, 2009). Családi közösségben 56-98\%, míg intézeti elhelyezés esetén $91-96 \%$ az előfordulási gyakoriság. A betegek 50\%-ánál több mint 4 tünet egyszerre jelenik meg (Frisoni, Rozzini és munkatársai, 1999).

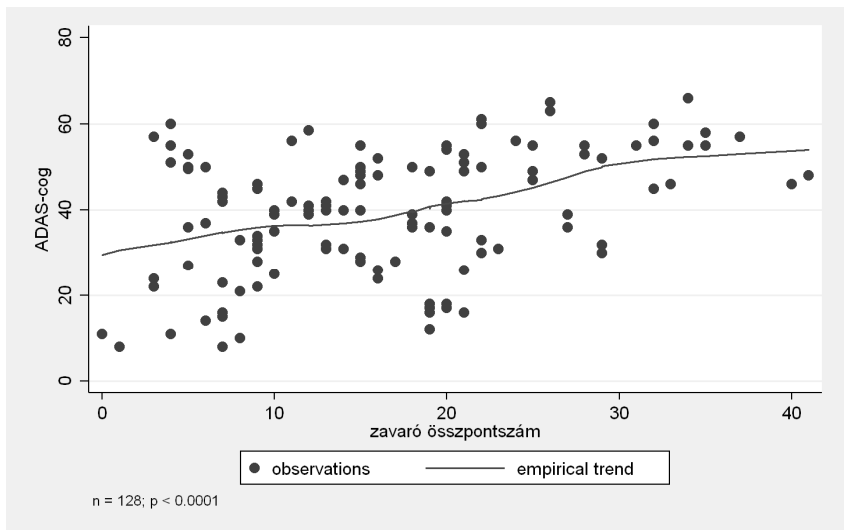

6. ábra. A kognitív funkcióinak romlása és a hozzátartozó terhe.

Az NPS tünetek erős hatással vannak mind fizikálisan mind pszichésen a gondozóra. A gondozási idő és distressz jelentős része valamilyen NPS tünet miatt van (Ballard, Neill és munkatársai, 2000), és ez az egyik legföbb oka a korai intézménybe kerülésnek (Chan, Kasper és munkatársai, 2003). Az ápolási otthonba való elhelyezés jelentős költségnövekedést okoz az egyéb ápolási költségek mellett (Beeri, Werner és munkatársai, 2002). A gondozó számára a legmegterhelöbb a pszichotikus tünetek és a bomlasztó viselkedésformák, pl, agresszió, agitáció stb. (Miyamoto, Tachimori, Ito, 2010). A hozzátartozó teher alapján saját mintánkban a legnagyobb teher a kóros motoros magatartás, depresszió, agitáció, evés-étvágy változása, téveszme esetében jelent meg. Ezek ez eredmények összhangban vannak számos korábban publikált kutatási eredményekkel is (Lanaro, Amenta, és munkatársai 2006).

A hozzátartozó pszichésen és szomatikusan dekompenzálódik, saját fizikális és mentális egészsége romlik, gyengülnek a megoldási képességek és stratégiák (Rabins, Mace, Lucas, 1982). A leggyakoribb tünetek a fáradtság, alvászavar, étvágyzavar, hangulati labilitás, irritabilitás (Mittelman, Roth és munkatársai, 2004). Ezek a tünetek gyakran önmagukban is kezelést igénylenek.

Az életminőség, betegségteher és a neuropszichiátriai tünetek tekintetében erős szignifikáns összefüggést találtunk, mely összhangban van a szakirodalmi 
adatokkal, bár kevés olyan vizsgálat történt,hol a betegek életminőségét és betegségterhét mérték. A legtöbb esetben a hozzátartozó, vagy ápoló személyzet életminősége és terhe volt a kutatások közzépontjában. Banerjee és munkatársai, egy 2006-os 101 demens beteget vizsgáló kutatásban arra a következtetésre jutottak, hogy a neuropszichiátriai tünetek háromszor olyan erős kapcsolatban vannak az életminőséggel, mint a kognitív tünetek (Banerjee, Smith és munkatársai, 2006). Egy 2006-os brit kutatás hasonló eredményekkel zárult, és külön kiemelték, hogy a depresszió és szorongás szintje erősen korrelál az életminőség mutatókkal (Hoe, Hancock és munkatársai, 2006). Hurt és munkatársai 2008-as kutatásukban, melyben 46 demens beteg és 116 hozzátartozó vizsgálata történt meg azzal a céllal, hogy megnézzék az NPS tünetek és az életminőség összefüggéseit, arra a következtetésre jutottak, hogy az NPS tünetek mind a betegek mind a hozzátartozók esetében negatívan kapcsolatban állt az életminőséggel és a betegségteherrel (Hurt, Bhattacharyya és munkatársai, 2008).

\section{Konklúziók}

Kutatásunk fő célja az volt, hogy felmérjük a neurokognitív zavarban szenvedő betegek neuropszichiátriai tüneteit és ezek kapcsolatát különböző életminőség mutatókkal. Tudomásunk szerint ez az első ilyen irányú vizsgálat Magyarországon. A felmérés igényét az jelentette, hogy a demencia kutatások elsősorban erre a tünetcsoportra fókuszálnak a megfelelő és hatékonyabb gondozás és a jobb erőforrás-kihasználás érdekében. Kutatási eredmények igazolják (Orrell, Hancock és munkatársai, 2008), hogy a hosszabb ideig saját otthonban tartózkodás, pozitív hatással van a beteg prognózisára, életminőségére, ezért az irányvonal ennek a biztosítása, melyhez az első lépés a problémafelmérés.

A demens betegek ellátásának legfőbb elve, hogy a demens beteg számára folyamatosan a biztonság és a kényelem érzését, az élethelyzet feletti kontroll élményét és élvezetét, valamint a különböző stresszhelyzetek minimalizálást kell elérnünk a demencia állapot súlyosságának megfelelö pozitív stimulációs hatások fenntartása mellett (Brodaty, Green, Koschera, 2003). A tapasztalatok azt mutatják, hogy a stresszhelyzetek nagy része a demens betegek életében kiküszöbölhető lenne, ha a gondozónak pontosabb ismeretei lennének a betegség lefolyásával kapcsolatban. Ehhez nagyban hozzájárulhatnak kutatási eredményeink, hiszen számos olyan irányvonal rajzolódik ki belöle, amely megszabhatja egy későbbi cselekvési terv irányvonalát. A nem farmakológiai kezelés alappillére a demens betegek emocionális érzékenysége, ami még súlyos esetben is megtartott lehet. (Magai, Cohen, Gomberg, 2002). Ennek megfelelően a betegek szinte hibátlanul tudják kódolni a non-verbális kommunikációs jeleket és ezt az adott- 
ságukat ki lehet használni a megfelelő gondozási magatartás kialakítsa során. (Cohen-Mansfield, Mintzer, 2005). Folyamatosan törekedni kell a nyugodt környezet kialakítására, rugalmas gondozói magatartás mellett (Ayalon, Gum, és munkatársai, 2006).

A fenti gondozási elvek alapján egyértelmüen kirajzolódik, hogy neurokognitív zavarban szenvedő betegek ellátása során egy komplex szemlélet kialakítására van szükség, ahol az orvos, a beteg, a hozzátartozó/gondozó, és az egyéb segítő szakemberek teamet alkotva segítik a betegséggel való együttélést. Emiatt is kiemelten fontos a neuropszichiátriai tünetek tisztázása és a folyamat monitorozása, követése. Kutatásunk az első lépése egy olyan komplex gondozási program kidolgozásának, melyben fontos szerepet kap a hozzátartozó. Ennek első szakasza volt az NPS tünetek felmérése, azzal a céllal, hogy jobb és pontosabb edukációt tudjunk nyújtani a betegnek és családjának. Fel tudjuk őket készíteni, milyen tünetek/életviteli nehézségek várhatóak, mi az, ami ennek a betegségnek a része, és mely tünetre kell fokozottabban figyelni.

\section{Irodalomjegyzék}

1. Alzheimer's Association. Alzheimer's disease facts and figures. Alzheimers Dementia. 2010 Mar; 6 (2):158-94.

2. Alzheimer's Association. Alzheimer's disease facts and figures. Alzheimers Dementia. 2014 Mar; 10 (2):47-92.

3. Ayalon L, Gum AM, Feliciano L, Areán PA (2006): Effectiveness of nonpharmacological interventions for the management of neuropsychiatric symptoms in patients with dementia: a systematic review. Archives of Internal Medicine (166), 20: 2182-2188.

4. Ballard C, Neill D, O'Brien J, McKeith IG, Ince P, Perry R (2000): Anxiety, depression and psychosis in vascular dementia: prevalence and associations. Journal of Affective Disorder (59), 2: 97-106.

5. Banerjee S, Smith S C , Lamping D L, Harwood R H, Foley B, Smith P, Murray J, Prince M, Levin E, Mann A, Knapp M (2006): Quality of life in dementia: more than just cognition. An analysis of associations with quality of life in dementia. Journal of neurology, neurosurgery, and psychiatry (77), 2: $146-148$.

6. Beeri MS, Werner P, Davidson M, Noy S (2002): The cost of behavioral and psychological symptoms of dementia (BPSD) in community dwelling Alzheimer's disease patients. International Journal of Geriatric Psychiatry (17), 5:403-408. 
7. Brodaty H, Green A, Koschera A (2003): Meta-analysis of psychosocial interventions for caregivers of people with dementia. Journal of the American Geriatrics Society (51), 5: 657-664.

8. Chan DC, Kasper JD, Black BS, Rabins PV(2003). Presence of behavioral and psychological symptoms predicts nursing home placement in community-dwelling elders with cognitive impairment in univariate but not multivariate analysis. Journal of Gerontology A Biological Science Medical Science (58), 6: 548-554.

9. Clare L, Rowlands J, Bruce E, Surr C, Downs M (2008). The experience of living with dementia in residential care: an interpretative phenomenologiacal analysis. Gerontologist (48),6 :711-720.

10. Cohen-Mansfield J, Mintzer JE (2005) Time for change: the role of nonpharmacological interventions in treating behavior problems in nursing home residents with dementia. Alzheimer Dissease Association Disorder (19), 1:37-40.

11. Cooper C, Sommerlad A, Lyketsos CG, Livingston G (2015). Modifiable predictors of dementia in mild cognitive impairment: a systematic review and meta-analysis. American Journal of Psychiatry (172), 4: 323-334.

12. Cummings JL, Mega M, Gray K, Rosenberg-Thompson S, Carusi DA, Gornbein J (1994). The Neuropsychiatric Inventory Comprehensive assessment of psychopathology in dementia. Neurology (44),12: 2308-2314.

13. Feast A, Orrell M, Charlesworth G, Melunsky N, Poland F, Moniz-Cook E (2008). Behavioural and psychological symptoms in dementia and the challenges for family carers: systematic review. The British Journal of Psychiatry (208), 5:429-434.

14. Folstein M, Folstein SE, McHugh PR (1975). "Mini-Mental State" a Practical Method for Grading the Cognitive State of Patients for the Clinician. Journal of Psychiatric Research (12), 3:189-198.

15. Frisoni GB, Rozzini L, Gozzetti A, Binetti G, Zanetti O, Bianchetti A, Trabucchi M, Cummings JL (1999). Behavioral syndromes in Alzheimer's disease: description and correlates. Dementia and Geriatric Cognitive Disorder (10), 2:130-138.

16. Gitlin LN, Piersol CV, Hodgson N, Marx K, Roth DL, Johnston D, Samus Q, Pizzi L, Jutkowitz E, Lyketsos CG (2016). Reducing neuropsychiatric symptoms in persons with dementia and associated burden in family caregivers using tailored activities: Design and methods of a randomized clinical trial. Contemporary Clinical Trials (49),11:92-102.

17. Hoe J, Hancock G, Livingston G, Orrell M (2006). Quality of life of people with dementia in residential care homes. The British Journal of Psychiatry (188), 5: 460-464. 
18. Hurt C, Bhattacharyya S, Burns, Camus V, Liperoti R, Marriott A, Nobili F, Robert P, Tsolaki M, Vellas B, Verhey F, Byrne E.J (2008) Patient and Caregiver Perspectives of Quality of Life in Dementia. An Investigation of the Relationship to Behavioural and Psychological Symptoms in Dementia. Dementia and Geriatric Cognitive Disorder (26),2: 138-146.

19. Kálmán J, Kálmán S, Pákáski M (2008): Demenciákhoz társuló viselkedési és pszichés zavarok felismerése és kezelése antipszichotikumokkal: A CATIE-ad vizsgálat tanulságai. Neuropsychopharmacologia Hungarica (10), 4: 233-248.

20. Lanaro A, Amenta F, Silvestrelli G, Tomaasoni D, Parnetti L (2006): Neurotransmitter deficit sin behavioural and psychological symptoms of Alzhiemer's disease. Mechanism of Ageing and Develpment (127),2: 158165.

21. Lyketsos CG, Carrillo MC, Ryan JM, Khachaturian AS, Trzepacz P, Amatniek,J, Miller DS (2011): Neuropsychiatric symptoms in Alzheimer's disease. Alzheimers Dementia (7), 5: 532-539.

22. Magai C, Cohen CI, Gomberg D (2002): Impact of training dementia caregivers in sensitivity to nonverbal emotion signals. International Psychogeriatrics (14), 1: 25-38.

23. McKeith I, Cummings J (2005): Behavioural changes and psychological symptoms in dementia disorders. Lancet Neurology (4),11: 735-742.

24. Mittelman MS, Roth DL, Coon DW, Haley WE (2004): Sustained benefit of supportive intervention for depressive symptoms in caregivers of patients with Alzheimer's disease. American Journal of Psychiatry (161),5:850-856.

25. Miyamoto Y, Tachimori H, Ito H (2010): Formal caregiver burden in dementia: impact of behavioral and psychological symptoms of dementia and activities of daily living. Geriatric Nursing (31),4:246-253.

26. Monastero R, Mangialasche F, Camarda C, Ercolani S, Camarda R (2009): A systematic review of neuropsychiatric symptoms in mild cognitive impairment. Journal of Alzheimers Disease (18),1:11-30.

27. Novak M, Mah K, Molnar M, Ambrus Cs, Csepanyi G, Kovacs A, Vamos E, Zambo M, Zoller R, Mucsi I, Devins GM (2005): Factor structure and reliability of the Hungarian version of the Illness Intrusiveness Rating Scale: invariance across North American and Hungarian dialysis patients. Journal of Psychosomatic Research (58), 1:103-110.

28. Orrell M, Hancock GA, Liyanage KC, Woods B, Challis D, Hoe J (2008): The needs of people with dementia in care homes: the perspectives of users, staff and family caregivers. Journal of Internatonal Psychogeriatrics (20), 5: 941-951. 
29. Pákáski M, Drótos G, Janka Z, Kálmán J (2012): Az Alzheimer's Disease Assessment Scale kognitív alskála magyar verziójának validálása. Orvosi Hetilap (153), 12: 461-466.

30. Rabins PV, Mace NL, Lucas MJ (1982): The impact of dementia on the family. Jama (248), 3:333-335.

31. Rosen WG, Mohs RC, Davis KL (1984): A new rating scale for Alzheimer's Disease. American Journal of Psychiatry (141), 11:1356-1364.

32. Ryu SH, Ha JH, Park DH, Yu J, Livingston (2011): Persistence of neuropsychiatric symptoms over six months in mild cognitive impairment in community-dwelling Korean elderly. International Psychogeriatrics. (23), 2: 214-20.

33. Susánszky É, Konkoly TB, Stauder A, Kopp M (2006): A WHO-jóllét kérdőív rövidített (WBI-5) magyar változatának validálása a Hungarostudy 2002 országos lakossági egészségfelmérés alapján. Mentálhigiéné és Pszichoszomatika (7), 3:247-255.

\section{Majer Réka}

A Debreceni Egyetem Bölcsésztudományi Karán végzett alapképzésen viselkedéselemzőként, majd a Debreceni Egyetem Magatartástudományi Intézetében szerezte meg kitüntetéses Msc diplomáját, okleveles egészségpszichológusként. A diploma megszerzése után Phd képzésben folytatta tanulmányait a Debreceni Egyetem Pszichiátriai Klinikáján az Idegtudományi Doktori Iskola berkein belül, ahol a demenciával való együttélés lett fő kutatási területe. Ezzel egy időben tudományos munkássága mellett a szakmát a Debreceni Egyetem Onkológiai Klinikáján gyakorolta, ahol már 5. éve onkopszichológusként dolgozik. Emellett jelenleg a Debreceni Egyetem Egészségügyi Karának tanársegédje. 
